
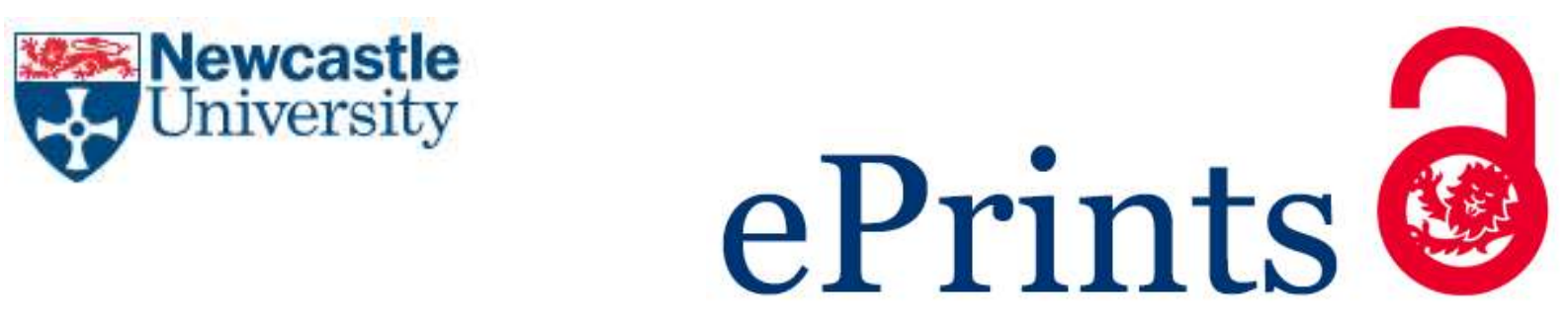

McKean C, Law J, Mensah F, Eadie P, Frazer K, Reilly S. Predicting meaningful differences in school-entry language skills from child and family factors measured at 12 months of age. International Journal of Early Childhood 2016

Copyright:

The final publication is available at Springer via http://dx.doi.org/10.1007/s13158-016-0174-0

Date deposited:

$26 / 09 / 2016$

Embargo release date:

21 September 2017

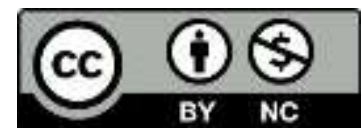

This work is licensed under a Creative Commons Attribution-NonCommercial 3.0 Unported License 


\section{International Journal of Early Childhood}

\section{Predicting meaningful differences in school-entry language skills from child and family factors measured at 12 months of age \\ --Manuscript Draft--}

\begin{tabular}{|c|c|c|}
\hline \multicolumn{3}{|l|}{ Manuscript Number: } \\
\hline Full Title: & \multicolumn{2}{|c|}{$\begin{array}{l}\text { Predicting meaningful differences in school-entry language skills from child and family } \\
\text { factors measured at } 12 \text { months of age }\end{array}$} \\
\hline Keywords: & \multicolumn{2}{|c|}{$\begin{array}{l}\text { language development; early identification; language impairment; screening; risk; } \\
\text { longitudinal cohort; early intervention; prevention }\end{array}$} \\
\hline \multicolumn{3}{|l|}{$\begin{array}{l}\text { Corresponding Author Secondary } \\
\text { Information: }\end{array}$} \\
\hline First Author: & \multicolumn{2}{|l|}{ Cristina McKean, PhD } \\
\hline \multicolumn{3}{|l|}{ First Author Secondary Information: } \\
\hline \multirow[t]{6}{*}{ Order of Authors: } & \multicolumn{2}{|l|}{ Cristina McKean, PhD } \\
\hline & \multicolumn{2}{|l|}{ James Law } \\
\hline & \multicolumn{2}{|l|}{ Fiona Mensah } \\
\hline & \multicolumn{2}{|l|}{ Eileen Cini } \\
\hline & \multicolumn{2}{|l|}{ Tricia Eadie } \\
\hline & \multicolumn{2}{|l|}{ Sheena Reilly } \\
\hline \multirow{7}{*}{ Funding Information: } & $\begin{array}{l}\text { National Health and Medical Research } \\
\text { Council } \\
\text { (9436958) }\end{array}$ & Prof Sheena Reilly \\
\hline & $\begin{array}{l}\text { National Health and Medical Research } \\
\text { Council } \\
(1041947)\end{array}$ & Prof Sheena Reilly \\
\hline & $\begin{array}{l}\text { National Health and Medical Research } \\
\text { Council } \\
(1023493)\end{array}$ & Prof Sheena Reilly \\
\hline & $\begin{array}{l}\text { National Health and Medical Research } \\
\text { Council } \\
(1037449)\end{array}$ & Dr Fiona Mensah \\
\hline & $\begin{array}{l}\text { National Health and Medical Research } \\
\text { Council } \\
(1111160)\end{array}$ & Dr Fiona Mensah \\
\hline & $\begin{array}{l}\text { National Health and Medical Research } \\
\text { Council } \\
(1041892)\end{array}$ & Prof Sheena Reilly \\
\hline & $\begin{array}{l}\text { National Health and Medical research } \\
\text { Council } \\
(1023493)\end{array}$ & Prof James Law \\
\hline
\end{tabular}




\section{Abstract:}

Abstract

Early childhood services which seek to promote early language development are hampered by the absence of reliable methods to identify children who may develop persistent language difficulties.

This is because of variability in preschool children's language development and that existing measures have limited diagnostic accuracy. In this study, we examined two approaches to identifying children at 12 months of age who are at risk of poor language skills at 4 years of age: (1) measurement of socio-cognitive and communicative foundations of language using the 'Sure Steps to Talking' (SSTT) Questionnaire; (2) a 'combined risk model' utilising child, family and parenting characteristics. The study had three phases: (1) evaluation of the predictive validity of SSTT through longitudinal follow-up of children in a matched cohort in the United Kingdom; (2) modelling application of SSTT as a population screener and assessing its validity in a longitudinal community cohort in Australia (Early Language in Victoria Study ELVS); (3) evaluation of a list of risk factors through secondary data analysis of the ELVS cohort. Prediction using the SSTT measure was modest. A 'risk model' that included seven factors (child communicative behaviours, family and parenting characteristics) measured at 12 months, reached 'fair' levels of predictive validity and approached a similar level of prediction for language difficulties at age 4 years as found by measures of vocabulary at 24 months. This latter assessment approach potentially provides an additional 12-month window within which preventative interventions could be implemented.

Keywords: language development; early identification; language impairment; screening; risk; longitudinal cohort; early intervention; prevention

\section{Résumé}

Les services aux jeunes enfants qui cherchent à promouvoir le développement du langage sont gênés par l'absence de méthodes fiables permettant d'identifier les enfants qui pourraient développer des difficultés persistantes du langage. Ceci est dû à la variabilité du développement du langage chez les enfants d'âge préscolaire et au fait que les mesures existantes ont une précision de diagnostic limitée. Dans cette étude, nous avons examiné deux approches pour identifier les enfants de 12 mois qui risquent d'avoir de faibles habiletés langagières à l'âge de 4 ans: (1) la mesure des fondements sociocognitifs et communicatifs du langage à l'aide du questionnaire «Sure Steps To Talking» (SSTT, Des étapes sûres vers la parole) ; (2) un «modèle de risques combinés» faisant appel aux caractéristiques de l'enfant, de la famille et du rôle parental. L'étude s'est déroulée en trois phases: (1) évaluation de la validité prédictive du SSTT au moyen du suivi longitudinal des enfants d'une cohorte comparable au Royaume-Uni ; (2) modélisation de l'application du SSTT pour trier une population et évaluation de sa validité auprès de la cohorte longitudinale d'une collectivité australienne (Early Language in Victoria Study, ELVS, Étude du langage des jeunes enfants du Victoria); (3) évaluation d'une liste de facteurs de risques par une analyse de données secondaires de la cohorte de l'ELVS. La prédiction par la mesure SSTT s'est avérée modeste. Un «modèle de risque» comprenant sept facteurs (comportements communicatifs de l'enfant, caractéristiques de la famille et du rôle parental) mesurés à 12 mois a permis d'atteindre de «bons» niveaux de validité prédictive et a avoisiné un niveau semblable de prédiction de difficultés de langage à l'âge de 4 ans comme l'ont révélé des mesures de vocabulaire à 24 mois. Cette dernière approche d'évaluation apporte un créneau potentiel de 12 mois supplémentaires au cours desquels des interventions préventives pourraient être mises en œuvre.

Resumen

Los servicios de niñez temprana que buscan promover el desarrollo lingüístico 
temprano enfrentan obstáculos debido a la ausencia de métodos confiables para identificar a aquellos que puedan desarrollar dificultades persistentes en la adquisición de lenguaje. Esto se debe a la diversidad en el desarrollo lingüístico de niños y niñas en edad pre-escolar y al hecho de que la exactitud diagnóstica de las medidas existentes es limitada. Este estudio examina dos métodos para identificar a niños/as de 12 meses de edad en riesgo de presentar escasas habilidades lingüísticas a los cuatro años de edad: (1) medición de bases lingüísticas socio-cognitivas y comunicativas utilizando el Cuestionario "Pasos Seguros para el Habla" [Sure Steps to Talking (SSTT, por su abreviatura en inglés)]; (2) un 'modelo de riesgo combinado' que utiliza las características del niño/a, la familia y el estilo de crianza. El estudio tiene tres fases: (1) evaluación de la validez predictiva del cuestionario SSTT por medio de un seguimiento longitudinal de niños/as en una población base equiparada en el Reino Unido; (2) aplicación modelo de SSTT como un filtro de población y evaluación de su validez en una comunidad longitudinal base en Australia (Estudio de Lenguaje Temprano en Victoria [ELVS, por su abreviatura en inglés]; (3) evaluación de una lista de factores de riesgo mediante el análisis de información secundaria de la población base ELVS. La predicción lograda utilizando la medida SSTT fue modesta. Un "modelo riesgo" que incluyo siete factores (comportamiento comunicativo de los niños, características de las familias y de la crianza) medidos a los 12 meses de edad, alcanzaron niveles "equitativos" de validez predictiva y lograron alcanzar un nivel similar de predicción de dificultades lingüísticas a los 4 años de edad, según lo descubierto con las mediciones del vocabulario a los 24 meses de edad. Este último método de evaluación brinda un período de oportunidad de 12 meses durante el cual se pueden llevar a cabo intervenciones de prevención. 


\section{Predicting meaningful differences in school-entry language skills from child and}

\section{family factors measured at 12 months of age}

Cristina McKean ${ }^{1,2}$; James Law ${ }^{1}$; Fiona Mensah ${ }^{2,3,4}$; Eileen Cini²; Patricia Eadie ${ }^{3}$; Kath Frazer ${ }^{5}$, Sheena Reilly $2,3,6$

${ }^{1}$ Newcastle University, King George VI Building, Queen Victoria Rd, Newcastle upon Tyne, NE1 7RU, United Kingdom

${ }^{2}$ Murdoch Children's Research Institute, Royal Children's Hospital, Flemington Road, Parkville, Melbourne, Victoria 3052, Australia

${ }^{3}$ University of Melbourne, Melbourne, Victoria 3010, Australia

${ }^{4}$ Royal Children's Hospital, Flemington Road, Parkville, Melbourne, Victoria 3052, Australia

${ }^{5}$ Northumbria Healthcare NHS Foundation Trust, North Tyneside General Hospital, Rake Lane, North Shields NE29 8NH, United Kingdom

${ }^{6}$ Menzies Health Institute Queensland, Griffith University, Parklands Drive, Southport, Queensland 4222, Australia

Corresponding author contact: email: cristina.mckean@ncl.ac.uk; Tel: +44 (0) 1912086528

Acknowledgements

The Early Language Victoria Study was funded by the Australian National Health and Medical Research Council (NHMRC \#237106, \#9436958 and \#1041947). The authors thank the members of the Early Language Victoria Study team and all participating families and acknowledge the support of the NHMRC-funded Centre of Research Excellence in Child Language (\#1023493). (C. McKean, Centre of Research Excellence, \#1023493, F. Mensah, Early Career Fellowship \#1037449, Career Development Fellowship \#1111160, S. Reilly, Practitioner Fellowship \#1041892, J. Law, Centre of Research Excellence, \#1023493). Research at the Murdoch Children's Research Institute is supported by the Victorian Government's Operational Infrastructure Support Program. The Northumberland Early Identification of Communication Delay (NEICD) Project was funded from the Flexibility and Sustainability Fund provided by the National Institute for Health Research. The authors thank the parents of the children in the study; Speech and Language Therapists Lynne Ross and Amy Pegram for their contribution to data collection; Neil McCarthy, NHS information analyst; Mark Pearson, Newcastle University; the health visiting and speech and language therapy staff for making this study possible and to Sue Welsh for her continuing support for SLT research. 
Predicting school-entry language skills at 1 year

\section{Abstract}

Early childhood services which seek to promote early language development are hampered by the absence of reliable methods to identify children who may develop persistent language difficulties. This is because of variability in preschool children's language development and that existing measures have limited diagnostic accuracy. In this study, we examined two approaches to identifying children at 12 months of age who are at risk of poor language skills at 4 years of age: (1) measurement of socio-cognitive and communicative foundations of language using the 'Sure Steps to Talking' (SSTT) Questionnaire; (2) a 'combined risk model' utilising child, family and parenting characteristics. The study had three phases: (1) evaluation of the predictive validity of SSTT through longitudinal follow-up of children in a matched cohort in the United Kingdom; (2) modelling application of SSTT as a population screener and assessing its validity in a longitudinal community cohort in Australia (Early Language in Victoria Study ELVS); (3) evaluation of a list of risk factors through secondary data analysis of the ELVS cohort. Prediction using the SSTT measure was modest. A 'risk model' that included seven factors (child communicative behaviours, family and parenting characteristics) measured at 12 months, reached 'fair' levels of predictive validity and approached a similar level of prediction for language difficulties at age 4 years as found by measures of vocabulary at 24 months. This latter assessment approach potentially provides an additional 12-month window within which preventative interventions could be implemented.

Keywords: language development; early identification; language impairment; screening; risk; longitudinal cohort; early intervention; prevention 
Predicting school-entry language skills at 1 year

\section{Résumé}

Les services aux jeunes enfants qui cherchent à promouvoir le développement du langage sont gênés par l'absence de méthodes fiables permettant d'identifier les enfants qui pourraient développer des difficultés persistantes du langage. Ceci est dû à la variabilité du développement du langage chez les enfants d'âge préscolaire et au fait que les mesures existantes ont une précision de diagnostic limitée. Dans cette étude, nous avons examiné deux approches pour identifier les enfants de 12 mois qui risquent d'avoir de faibles habiletés langagières à l'âge de 4 ans: (1) la mesure des fondements sociocognitifs et communicatifs du langage à l'aide du questionnaire «Sure Steps To Talking» (SSTT, Des étapes sûres vers la parole) ; (2) un «modèle de risques combinés» faisant appel aux caractéristiques de l'enfant, de la famille et du rôle parental. L'étude s'est déroulée en trois phases: (1) évaluation de la validité prédictive du SSTT au moyen du suivi longitudinal des enfants d'une cohorte comparable au Royaume-Uni ; (2) modélisation de l'application du SSTT pour trier une population et évaluation de sa validité auprès de la cohorte longitudinale d'une collectivité australienne (Early Language in Victoria Study, ELVS, Étude du langage des jeunes enfants du Victoria); (3) évaluation d'une liste de facteurs de risques par une analyse de données secondaires de la cohorte de l'ELVS. La prédiction par la mesure SSTT s'est avérée modeste. Un «modèle de risque» comprenant sept facteurs (comportements communicatifs de l'enfant, caractéristiques de la famille et du rôle parental) mesurés à 12 mois a permis d'atteindre de «bons» niveaux de validité prédictive et a avoisiné un niveau semblable de prédiction de difficultés de langage à l'âge de 4 ans comme l'ont révélé des mesures de vocabulaire à 24 mois. Cette dernière approche d'évaluation apporte un créneau potentiel de 12 mois supplémentaires au cours desquels des interventions préventives pourraient être mises en œuvre. 
Predicting school-entry language skills at 1 year

\section{Resumen}

Los servicios de niñez temprana que buscan promover el desarrollo lingüístico temprano enfrentan obstáculos debido a la ausencia de métodos confiables para identificar a aquellos que puedan desarrollar dificultades persistentes en la adquisición de lenguaje. Esto se debe a la diversidad en el desarrollo lingüístico de niños y niñas en edad pre-escolar y al hecho de que la exactitud diagnóstica de las medidas existentes es limitada. Este estudio examina dos métodos para identificar a niños/as de 12 meses de edad en riesgo de presentar escasas habilidades lingüísticas a los cuatro años de edad: (1) medición de bases lingüísticas socio-cognitivas y comunicativas utilizando el Cuestionario "Pasos Seguros para el Habla" [Sure Steps to Talking (SSTT, por su abreviatura en inglés)]; (2) un 'modelo de riesgo combinado' que utiliza las características del niño/a, la familia y el estilo de crianza. El estudio tiene tres fases: (1) evaluación de la validez predictiva del cuestionario SSTT por medio de un seguimiento longitudinal de niños/as en una población base equiparada en el Reino Unido; (2) aplicación modelo de SSTT como un filtro de población y evaluación de su validez en una comunidad longitudinal base en Australia (Estudio de Lenguaje Temprano en Victoria [ELVS, por su abreviatura en inglés]; (3) evaluación de una lista de factores de riesgo mediante el análisis de información secundaria de la población base ELVS. La predicción lograda utilizando la medida SSTT fue modesta. Un "modelo riesgo" que incluyo siete factores (comportamiento comunicativo de los niños, características de las familias y de la crianza) medidos a los 12 meses de edad, alcanzaron niveles "equitativos" de validez predictiva y lograron alcanzar un nivel similar de predicción de dificultades lingüísticas a los 4 años de edad, según lo descubierto con las mediciones del vocabulario a los 24 meses de edad. Este último método de evaluación brinda un período de oportunidad de 12 meses durante el cual se pueden llevar a cabo intervenciones de prevención. 
Predicting school-entry language skills at 1 year

\section{Introduction}

Robust language development in the pre-school years is essential if children are to enter school equipped to navigate the accompanying academic and social challenges (Catts et al. 2008). Language is the system, either spoken or written, that defines the manner in which human's communicate. Speech is the process by which the lips and tongue and other organs of the vocal tract shape sounds thereby conveying meaning when sounds are combined (Reilly et al., 2015). A range of different terms, often used interchangeably, are used to describe these problems. These include overarching terms that group together a number of problems such as speech, language and communication needs and speech and language delay/disorders and terms that refer to a specific problem such as language impairment, language disorder and language difficulties (Sui 2015; Wallace et al., 2015; Bishop 2014; Reilly et al., 2014). In this paper we focus specifically on children whose language development, that is their ability to understand (receptive) or use (expressive) language, falls below age expectations and use the term language difficulties to refer to this group.

Children with language difficulties at school entry are at risk of poor adolescent and adult outcomes with respect to social-emotional wellbeing, literacy, mental health and employment (Law et al. 2009). A logical and important goal for pre-school services is to prevent children starting school with language difficulties. While there are clearly universal messages that can be disseminated to encourage good communication skills a more proportionate approach is likely to be necessary. Such approaches can include selective targeting of subpopulations considered to be 'at risk', (the method most commonly associated with preventative programmes such as Sure Start in England or Head Start in the US) or indicated targeting of children identified with a specific need. The latter tends to be the most common approach but tools to accurately identify children sufficiently early for preventative, targeted interventions to have maximum effect have remained elusive especially in young children. This study explores two approaches to this process, one based on parent reporting of the child's communicative behaviour at 12 months and the other a 'risk' model. We then compare the two approaches in terms of their ability to predict four-year language outcomes in two different 
Predicting school-entry language skills at 1 year

populations.

There has been growing recognition that child language outcomes are not simply the result of biological factors. Rather they are likely to result from multiple determinants and complex interactions, between the child's genetic and biological make-up, and social, environmental and economic factors (McKean et al. 2015). With this comes a number of important implications for policy and practice with respect to the promotion of language development for all children. First is the need to monitor the complex interactions between a child's language trajectory and the environment. Second, social and environmental factors which affect language development could be modified to promote protective factors and minimise risks. Third, if such preventative interventions can be put in place sufficiently early, there is the potential to prevent later language difficulties for some children.

The prevailing model applied to the identification and treatment of child language difficulties is biomedical, with a focus on 'case-finding' where children with significant language difficulties are identified and treatment is then provided. Recently Law et al. (2013) advocated a shift in focus in services for children with speech, language and communication difficulties to one of prevention. They outlined three categories of preventative intervention: Primary prevention, focusing on the population as a whole aiming to prevent children experiencing poor language development; Secondary prevention targeting groups of children at increased risk of developing language problems with a focus on slowing or halting the course of the condition; and Tertiary prevention provided to those with an identified language difficulties with the aim of minimising its negative effects on quality of life (Law et al. 2013).

The biomedical approach misses opportunities that may exist for primary prevention and makes secondary prevention problematic because we are currently unable to identify children with persisting language difficulties sufficiently accurately and early for interventions to be put in place before school (Reilly et al. 2014). By this time it is likely that any language difficulties will persist (Johnson et al. 1999). Waiting to deliver secondary prevention approaches until there is a confirmed 
Predicting school-entry language skills at 1 year

diagnosis may significantly limit the potential of such interventions to effect a substantial amelioration of the child's difficulty and impact on educational attainment generally.

Early primary and secondary prevention, as defined above, would therefore seem to be indicated, however the delivery of such provision in the developmental window from conception to 3 years is often complex and costly (Shonkoff 2011). Policy therefore tends to focus on indicated targeting early interventions for those who need it most through screening or surveillance programmes rather than as universal provision (Field 2010). There are two fundamental challenges inherent in such an approach: identifying accurately which children to 'target' and establishing when is the best time to do it.

\section{Screening and early identification}

As highlighted above, the development of tools for early identification and screening remains an appealing and important goal (Nelson et al. 2006 and more recently Sui 2015; Wallace et al., 2015). However, our knowledge of population level risks have not translated into reliable estimates of an individual's risk. At a population level a great deal is known about the factors which influence language development in the pre-school years including child, caregiver and community characteristics (Reilly et al. 2010). However, even in those studies with both sufficient power and breadth of measurement to build comprehensive risk models, a great deal of the variance in language abilities in the pre-school population remains unexplained (Reilly et al. 2010).

A further source of complexity lies in the volatility in language abilities of children with high levels of both resolution and emergence of difficulties over that period (Reilly et al. 2010; Zambrana et al. 2013). Studies evaluating universal screening of child language between 0 and 4 years have focussed predominantly on children between 2 and 4 years, the period of greatest variability (17 of the 20 language screening studies cited in the recent systematic review by Wallace et al., 2015). The most common approach applied in this age range is parental report, usually a vocabulary checklist and questions relating to the child's use and understanding of sentences (Wallace et al., 2015). The associations between children's early vocabulary knowledge when measured by such tools and later 
Predicting school-entry language skills at 1 year

language are relatively modest. For example correlations of .28 to .45 have been reported between MacArthur-Bates Communicative Development Inventories (MCDI) scores (Fenson et al. 1997) obtained at 17 to 30 months-of age and standardised language measures at 4;00, 4;06 and 6; 00 years (Lee 2011). These early language measures would therefore appear to be poor predictors of later language. This finding is counter-intuitive to many and leaves policy makers and practitioners with the question - if measuring children's language development is not sufficiently informative to plan and target early preventative services then what is? What is needed is a measure which can be administered very early in the child's language development which predicts language ability at school entry.

One potential alternative could be to 'bypass' the highly volatile period of language development between 2 and 4 years and, instead, to consider whether early communicative behaviours at 12 months, are a more reliable indicator of the risk of difficulties in language development at 4 years and rather than focus on vocabulary alone capture the child's orientation towards social communication more broadly. If such an approach were successful it would afford services a larger developmental window in which to deliver targeted preventative interventions.

The potential for predicting the risk of later language difficulties at 12 months

The rationale for a focus on the predictive value of identifying communication difficulties at 12 months of age is threefold. First, parental estimates of children's productive vocabulary have been shown to reduce in their reliability with age, with a peak in reliability between 12 and 14 months (Robinson and Mervis 1999). Second, recent population studies suggest that variability in child communication and language abilities at 8 and 12 months represent biologically rather than environmentally driven abilities of the child. Hence they may provide a more valid measure of the child's innate language learning potential than later measures (Reilly et al. 2010). Third, and possibly most importantly, the pragmatic infrastructure which is an essential precursor to symbolic language emerges at around 12 months-of-age (Tomasello 2008). Achievement of these socio-cognitive milestones is made evident through a number of readily observed behaviours (e.g. following the 
Predicting school-entry language skills at 1 year

attention and gestures of others; directing other's attention through pointing and showing). Given their significance and tangibility, a tool which measures the emergence of such skills at 12 months could be a highly reliable and powerful predictor of language growth.

\section{The current study}

It is important for pre-school services to identify young children who may be at risk of starting school with language difficulties. This study explores two approaches to the identification of children likely to have such difficulties at school-entry. The first is based on parent report of the child's communicative behaviour at 12 months and the second approach uses a 'risk' model incorporating child and family characteristics. In the analyses presented in this paper, we compare the two approaches in terms of their ability to predict language difficulties at 4 years in two different populations. The study is conducted in three phases.

Phase 1 evaluates the predictive validity of the Sure Steps to Talking (SSTT) measure that is a parent report measure of language at 12 months of age, through longitudinal follow-up of outcomes of children in a matched cohort study with children and families living in Northumberland in the United Kingdom. The SSTT is a measure of socio-cognitive and communicative development which can be readily integrated into primary care practices.

- At a group level do children who pass or fail the SSTT measure at 12 months differ in language ability at 4 years?

- At an individual level, what is the predictive accuracy of SSTT at 12 months with respect to the identification of children with language difficulties at 4 years?

Phase 2 evaluates the validity of a comparison measure developed from measures used in the Early Language in Victoria Study (ELVS) which is a longitudinal community cohort study involving children and families living in Victoria, Australia. In this phase, a population screening test is derived from parent-report measures used in ELVS that taps the constructs measured by the SSTT questions. We use replication across differing samples as a means of rigorously testing performance 
Predicting school-entry language skills at 1 year

- Is the level of predictive accuracy of SSTT found in Phase 1 replicable in a large community cohort?

Phase 3 develops a 'combined risk model' using the ELVS community cohort sample drawing on child and environmental factors to inform a targeted approach, wherein diagnostic screening and individual level identification are replaced by the delivery of services to broad groups of children considered to be 'at risk' (Law et al. 2013).

- What child, family, and environmental factors at 12 months may be readily applied by primary care practitioners to deliver the best estimates of 'risk' of language difficulties at 4 years?

- How does this 'combined risk model' compare to the MCDI at 12 months and 2 years?

\section{Methods}

In phase 1 a prospective longitudinal matched cohort methodology is employed to test the original SSTT tool in a cohort in Northumberland, UK. Phase 2 employed secondary analysis of data from ELVS, testing an ELVS-SSTT tool tapping similar constructs as the original tool and derived from parental questionnaires in the ELVS protocol. We use replication across differing samples as a means of rigorously testing performance. Phase 3 develops a 'combined risk model' in ELVS drawing on child and environmental factors.

\section{Phase 1: The Northumberland cohort.}

A total of 3047 children, born in Northumberland between 1st September 2006 and 31st August 2007, formed the sampling frame (Figure 1). Northumberland has a mixed socio-demographic profile and is the $53^{\text {rd }}$ most deprived local government area of 326 in England according to the English Indices of Multiple Deprivation (IMD) (ONS 2011). Sixteen of Northumberland's geographical areas fall in the most deprived $10 \%$ in the country. There is relative population stability and homogeneity of English as a first language (1.5\% of school-age children from a Non-English Speaking Background (NESB) (DfE 2010)). 
Predicting school-entry language skills at 1 year

Figure 1.

At 12 months, as part of routine health surveillance procedures, Health Visitors (specialist nurses delivering child and family health services in the UK from pregnancy to 5 years) completed the SSTT with parents. Copies of the questionnaires were sent to the Speech and Language Therapy service (children born between $1^{\text {st }}$ September 2006 and $31^{\text {st }}$ August 2007). Of the 2344 questionnaires returned to the service 2177 (92.9\%) met the threshold score of a 'pass' and 167 (7.1\%) scored 'fail'. In regard to the socio-demographic distribution of this sample (measured by the IMD) $57 \%$ of the children fell into English quintiles 1 and 2 (most deprived) and $43 \%$ in quintiles 3, 4 and 5 (least deprived). The mean age of the children on completion of the questionnaires was 12.6 months (SD 1.5). For the current analyses 256 children were identified from the cohort including, all the children who had 'failed' the SSTT questionnaire at 12 months. A group of children who 'passed', at 12 months were matched for gender, age (in months) and social disadvantage using the Postcode Lower Super Output Area (LSOA) (ONS 2011). Children were excluded from the analysis ( $n=49$ ) when it was not possible to find a matched child who had passed the SSTT, the family had moved, the child was too old or the parent refused to take part. In total 184 children were matched (92 pairs) although five children in the 'pass' group were identical for gender, age and LSOA and thus were able to act as controls for two children in the 'fail' group giving a total of 179 children assessed at four years. Of these 116 (64.8\%) were female. Ethical approval was obtained from the East of Scotland Research Ethics Service.

\section{Phases 2 and 3: the ELVS cohort}

The participants for this study were drawn from the longitudinal ELVS cohort; detailed sampling methods are reported elsewhere (Reilly et al. 2010). Briefly, between September 2003 and April 2004, a community sample of infants between 7.5 and 10 months were recruited in metropolitan Melbourne, Victoria, Australia. The 31 Local Government Areas (LGA) in metropolitan Melbourne were stratified into 3 tiers by their socio-demographic characteristics based on the SEIFA-Socioeconomic Indexes for Areas (Australian Bureau of Statistics 2001) and recruitment was conducted in 
Predicting school-entry language skills at 1 year

2 LGAs from each tier. The study is on-going and data has been collected at 10 waves, from 8 months to 11 years with a further wave at 13 years currently in the field. 1910 children were recruited at baseline (8 months) of whom 965 (50.5\%) were boys. This study draws on data collected at 12 months, 2 and 4 years (Figure 2).

The in-scope sample for this study applied the following exclusion criteria: at 12 months if questionnaire data was missing $(\mathrm{N}=89)$, and if the child was not within the age range $(9.6-15.6$ months) for this wave $(\mathrm{N}=2)$; at 4 years where questionnaire data and language test data were missing ( $\mathrm{N}=265$ and 85 respectively). Children from an NESB were also excluded ( $\mathrm{N}=125)$. This was in order to enable a comparison with the more homogeneous home language environments of the Northumberland cohort. The remaining 1398 children formed the in-scope sample, hereafter referred to as the ELVS cohort.

Figure 2

\section{Procedures}

Both cohorts used a combination of methods to obtain data including: (1) face-to-face interviews with the child's parent by Health Visitors (2) self-completion questionnaires by the child's parents and (3) direct language and cognitive testing by trained research associates blind to the child's previous test/questionnaire scores.

\section{Measures}

\section{SSTT}

The SSTT 12 item checklist (see Appendix) is administered by Health Visitors at 12 months-of-age as part of their universal one-year surveillance review in the North-East of England. It was developed through adaptation of SCREEN10 (Smith 1998), by Speech and Language Therapists in the region and was designed to assess behaviours indicative of the crucial pragmatic infrastructure necessary for language development (e.g. following the attention and gestures of others, directing other's attention, imitating communicative acts, and sharing attention). In addition, children's symbolic 
Predicting school-entry language skills at 1 year

understanding and understanding and use of words and phrases are measured, together with family history of speech and language difficulties and concerns about hearing. Following an earlier threshold analysis, children scoring 14 or less are considered to have failed. The internal consistency of the scale was tested and met acceptable levels (Cronbach's $\alpha$ of .74).

\section{ELVS-SSTT}

An ELVS-SSTT measure was also derived from parental questions used in the ELVS protocol at 12 months, which also focused on early communicative behaviours and which were close conceptual matches to those in the SSTT measure. This set of questions drew on the MCDI (Fenson et al. 1997), the Communication and Symbolic Behaviour Scales - Infant-Toddler Checklist (Wetherby and Prizant 2002) (which tap into vocabulary, early grammar and communication development) and additional research questions focussed on demographic, family and environmental factors (Appendix).

\section{Parent reported vocabulary}

In ELVS the MCDI (Fenson et al. 1997) was collected at 12 and 24 months. A child was identified as a Late Talker if their MCDI score at 2 years fell $\leq 10^{\text {th }}$ centile.

\section{Language Outcomes at 4 years}

In the Northumberland cohort the primary language outcome measure at 4 years was the Preschool Language Scales (PLS-4) (Zimmerman et al. 2002) and in ELVS was the CELF-P2 (Wiig et al. 2006). For both cohorts children were classified as having language difficulties at 4 years for a score 1.25 SD below the mean. Following Reilly et al. (2010), for the CELF-P2 children were classified as having language difficulties if either receptive or expressive language sub-scale scores fell below this cutpoint.

\section{Additional risk factors at 12 months}

The final phase aimed to identify a 'combined risk model' at 12 months. Risk factors included in the analysis were informed by other longitudinal studies of early risks for poor language outcomes at 4 to 5 years. We identified: from Reilly et al. (2010) gender, maternal education, socio-economic status, and birth weight; from Roulstone et al. (2011) parenting behaviours measured in ELVS using 
Predicting school-entry language skills at 1 year

the Brigance Infant Toddler Scale (BITS) (Brigance and Frances 2002); and from Law et al. (2012) the presence of child behavioural difficulties measured using questions from the Australian Temperament Scales (ATS) (Prior et al. 1989).

\section{Approach to Analysis}

Phase 1. Testing SSTT in a matched cohort

To examine the association between the SSTT measure and language and broader outcomes at age 4 years, we explored the mean differences between the language of the group of children who failed SSTT at 12 months and their matched controls. We used ROC analysis to determine predictive diagnostic accuracy (i.e. from 12 months to 4 years) yielding estimates of sensitivity and specificity and Area Under the Curve (AUC). These were then compared to cited 'acceptable' levels of sensitivity and specificity (70 to $90 \%$ ) and AUC (.61 to .69 , poor validity; .7 to .79 fair; .8 to .89 good; and $>.9$ excellent) (Kirkwood and Sterne 2003). These analyses are influenced by the prevalence of the trait being 'diagnosed', and so results were interpreted noting that the estimated performance of the tool would be affected by the increased prevalence of language difficulties at 4 years resulting from the sample selection procedures.

Phase 2. Testing ELVS-SSTT in a community cohort

Sensitivity, specificity, prevalence and the AUC were calculated for the ELVS-SSTT measure in the ELVS cohort.

Phase 3: Deriving and testing a 'combined risk model' in ELVS Logistic regression was used to estimate the odds that children with different early communication and symbolic development, family characteristics and parental behaviour at 12 months would have language difficulties at 4 years. We applied a hierarchical model such that candidate variables were entered sequentially into the model in a pre-determined order (see below). Individual variables were only retained in the final models where the $p$ value for the variable was <.1 and where the AUC for the model was significantly improved; again at a $p$ value $<.1$, the latter being tested using the predict 
Predicting school-entry language skills at 1 year

function in Stata (StataCorp. 2013). Variables, all measured at 12 months, were entered in the following order

a. ELVS-SSTT items: ranked according to $\mathrm{R}^{2}$ values derived from univariate linear regression with Language Composite Score CELF-P2 at 4 as the outcome variable.

b. Significant predictors from Reilly et al (2010): Gender, Maternal Education, Socio-economic status, Birth Weight.

c. Parental behaviours: questions from the BITS (Brigance and Frances 2002) were entered in the order asked as there was no a priori rationale for ordering: I play with my child and show him things; I help my child learn by talking and showing him/her new things; I look at or read children's books to my child; I make up games and songs for my child; When my child looks at or touches a toy, I talk to him/her about it.

d. Child behavioural difficulties: questions from the ATS (Prior et al. 1989) were entered in the order asked: My child has: sleep problems; excessive crying; temper tantrums; excessive shyness; over active; under active; accident prone; mood swings; is dependent.

Once a shortlist of significant variables was identified using the hierarchical analysis above, three models were generated with all variables entered into the model simultaneously. Model 1 included questions from the shortlist relating to child communicative behaviours, Model 2 added family characteristics and Model 3 added parental behaviours (Table 3). Finally the predictive power of the 'combined risk model' was compared to MCDI measures at 12 months and 2 years through the use of logistic regression to derive the AUC when MCDI measures were used as predictors of language outcome at 4 years.

\section{$\underline{\text { Results }}$}

\section{Phase 1: Testing SSTT in a matched cohort}

At a group level children who failed the SSTT at 12 months had significantly poorer outcomes at 4 years than their matched controls for language ability (Table 1). 
At an individual level the predictive sensitivity of the SSTT measure reached an acceptable level of $71.4 \%$ however sensitivity outweighed specificity, with the latter falling short of acceptable levels (53.4\%). The AUC for SSTT was 0.66 reaching poor levels of predictive diagnostic validity. The matched cohort design employed here may yield over-estimates of the sensitivity of the test. That is, the process of recruiting equal numbers of SSTT positives and negatives at 12 months is likely to have increased the number of children with language difficulties at 4 years in the sample to a level higher than would be usually found in a population and, as a result is likely to over-estimate the sensitivity of the test (Prevalence of language difficulties at 4 years: $19.6 \%)$. We therefore tested whether the promising levels of sensitivity were replicable in a community cohort.

\section{Phase 2: Testing ELVS-SSTT in a community cohort}

The levels of sensitivity in Phase 1 were not replicated in the ELVS cohort (66.0\%) and low levels of specificity were found (52.9\%; AUC: .63; Prevalence at 4 years: $17.21 \%)$.

\section{Phase 2: Deriving and testing a 'combined risk model' in ELVS}

Risk Model: Three models were derived from those predictors found to be significant: Model 1 including Communicative Behaviours, Model 2 adding Family Factors and Model 3 adding Parental Behaviours. In Model 1 three ELVS-SSTT items relating to child language and socio-cognitive behaviours independently predicted 4 year language status: 1) "Child extends arm to show you something s/he is holding" 2) "How many different words or phrases does your child understand without gestures, for example if you say "where's daddy", "give me the ball" or "come here" without showing or pointing your child will respond appropriately"; 3) "How many different words does your child use meaningfully" (Table 3). Significant family characteristics in Model 2 were Family History, SEIFA quintile, and Maternal Education. One question relating to parental behaviour was significant in Model 3: "When my child looks at/touches a toy, I talk about it". A child's odds of having language difficulties at 4 years were significantly reduced if parents responded 'sometimes' (OR: .37, 95\% Cl: 
Predicting school-entry language skills at 1 year

$.21-.64, p<.001$ ) or 'often' (OR: .30, 95\% Cl: .17 - .53, $p<.001$ ). No child behaviour variables were significant.

Table 2

Adding additional risk factors external to the child and which could be asked in clinical context produced a model with a higher AUC than the ELVS-SSTT measure (ELVS-SSTT $=.63$; Model 1 $=.63$; Model $2=.71 ;$ Model $3=.73$ ) with Models 2 and 3 reaching 'fair' levels of discrimination. Comparisons to MCDI: Comparison of the AUCs of the logistic regressions predicting child language status at 4 years, show that the AUC of the 'combined risk model' (Model 3: .73) approached that of the MCDI at 2 years (.76) and was greater than the predictor 'late talker' status at $2(.66)$ and the MCDI at 12 months (Production: .55 and Comprehension: .53). This risk model therefore provides similar predictive validity to the MCDI at 2 years but does so 12 months earlier in the child's life.

\section{Discussion}

In a matched cohort, early socio-cognitive and language behaviours at 12 months, as measured by the SSTT questionnaire, effectively identified groups of children that differed significantly on language, nonverbal ability, and social and emotional adjustment at 4 years. At an individual level the tool delivered acceptable levels of predictive sensitivity but not specificity when used to predict language status at 4 years, however, when tested in a community sample, much lower levels of sensitivity and hence diagnostic accuracy were found. When compared to MCDI measures in a community sample, early socio-cognitive and language behaviours as measured by the ELVS-SSTT, were a better predictor of 4-year language status than the 12-month MCDI but poorer than the MCDI at 2 years. However, a 'combined risk model' which identified a short-list of the most powerfully predictive questions from the SSTT measure and additional clinically applicable questions regarding child communicative behaviours, family characteristics and parental behaviours, 
Predicting school-entry language skills at 1 year

approached the predictive levels of the MCDI at 2 years, providing 'fair' levels of diagnostic accuracy and, importantly, did so one year earlier.

The results of this study demonstrate that it is possible to identify children at 12 months who are 'at risk' of language difficulties at four years. However, while early performance, as reported by the parent, is an indicator of risk of subsequent difficulties, it is only that. This is the first such study to demonstrate this outcome across the 12-48 months range and in two different cohorts of children. How the sample is derived clearly makes a difference, and matching 'passes' and 'fails', while helpful in maximising the number of cases studied, effectively inflates the accuracy figures, especially sensitivity. We then empirically tested a 'risk model' with results that are comparable in their predictive power to those from more traditional vocabulary screening measures at 24 months. The findings are significant for a number of reasons.

\section{Variability in child language development in the pre-school years}

It is deceptively appealing to assume that performance at one point is likely to predict performance at another very well. Our data fit well with other attempts to carry out early identification (Nelson et al. 2006) and with numerous studies demonstrating that children's relative language ability in the pre-school years can change significantly as they develop with some children having stable, some improving and some declining language trajectories (Reilly et al. 2010; Zambrana et al. 2013; Snowling et al., 2015). The degree of individual difference between children with respect to their biological make up, early processing and learning abilities, home learning experiences and the interactions between these factors make it extremely difficult to predict a child's rate of language growth in these early years. The findings of this study, that prediction from the end of the first year of life via a 'risk model' is comparable to prediction a year later from parental report of vocabulary knowledge, have not been demonstrated before. Our interpretation of this finding is that, notwithstanding the limitations discussed above, early language comprehension and social communication behaviours, when combined with additional family characteristics and parent behaviours, at twelve months are more useful than measures of vocabulary as a way of identifying 
Predicting school-entry language skills at 1 year

children's need. In other words they are more powerful than such measures at 12 months and roughly equivalent to those at 2 years, with the advantage of potentially providing an additional 12 months within which to offer preventative interventions.

\section{Timeliness of intervention}

The best outcomes for children are achieved when they receive optimal cognitive-linguistic stimulation and experience protective carer-child interactions throughout childhood (Shonkoff 2011). Despite this, there is a growing recognition that the crucial foundations of human development, upon which all other developmental achievements are built, are laid down very early (Shonkoff 2011) and that "what happens during the first months and years of life matters...because it sets either a sturdy or fragile stage for what follows" p. 5 (National Research Council and Institute of Medicine, 2000). The potential to estimate a child's risk of poor language development at 12 months could open up opportunities for the provision of proven targeted, primary prevention interventions in those crucial first months that traditional case-finding approaches miss (Lowell et al. 2011). Effectively we are making the argument for a risk focused approach to monitoring and intervening with respect to children's language development rather than the diagnostic and remediation model of case finding. How to operationalize this into recommendations for practice and policy however is not straightforward.

\section{A preventative approach}

It is possible that the reason a screen for language difficulties in the pre-school years has proved so elusive is not because of issues with the tools themselves but with the application of a diagnostic and remediation model to difficulties which may be better addressed within a preventative population approach. Perhaps, given our current knowledge of the causes and life-course of language difficulties, a secondary prevention, or targeted approach, wherein 'at risk' groups are identified and prevention/intervention offered to mitigate those risks, may be more appropriate, certainly in the pre-school years and, arguably beyond. 
Predicting school-entry language skills at 1 year

How might such an approach be practically implemented? Perhaps rather than dichotomising the population into 'at risk' or not at an arbitrary threshold score, a continuum of risk should be acknowledged with an accompanying continuum of response in terms of the amount and type of intervention offered. That is, children identified as being at the lowest risk would not receive targeted intervention but for all other children a sliding scale of risk could guide the tailoring of interventions and further investigations to the specific risks flagged.

Professionals engaged in delivering universal early child-care services (e.g. day-care staff, child-care workers, maternal and child health nurses, family workers, paediatricians, community midwives) could be readily trained to signpost families to appropriate support depending upon these risks. For example, directing those with a family history of speech and language difficulties, low socio-economic status or low maternal education to high quality early years provision and offering parenting programmes to those with delayed communicative development or limited parent child interaction. How this would be implemented would vary from one context to another and from country to country depending on the configuration of services and the nature of the populations served. Key to implementation would be identifying the appropriate mix of services and professional groups for the universal provision of the 'risk tool' and the accessible provision of parenting programmes for those who need them, perhaps integrating messages about language and communication development into existing early preventative programmes.

The questions in the 'combined risk' model could be developed to form the basis of a 'brief intervention' (World Health Organisation 2010) applying motivational interviewing techniques to direct parents' attention to child and parental behaviours which are the focus of a number of effective parent-implemented language interventions (Roberts and Kaiser 2011), promoting change in parenting practices and mitigating the risk of poor language development. Given that communicative behaviours are often entrenched and resistant to change, this may appear a naive suggestion. However, well designed and delivered brief interventions have been found to be 
Predicting school-entry language skills at 1 year

effective in reducing drug and alcohol use, behaviours traditionally thought to be highly resistant to modification (World Health Organisation 2010).

We recommend future research evaluate the effectiveness of embedding a combined risk tool and brief language intervention into service delivery models which incorporate either 'proportionate universalism' (Marmot et al. 2010) or 'stepped interventions' (Hambidge et al. 2009). In a model of proportionate universalism, families with greater social resources and capacity to change could receive the brief intervention whilst those with fewer resources and more entrenched patterns might receive a more guided and supported approach. In a stepped model, a brief intervention might constitute the first intervention for all 'at risk' children with additional interventions offered only to those who continue to have delays at two years. This would also open up the potential for staged risk models to be developed wherein key factors at different developmental stages could be combined making case finding a continuing process not a 'once and for all' project.

\section{Study Limitations}

The ELVS and Northumberland cohorts are constituted rather differently with respect to socioeconomic factors. This may have made a difference in terms of identification rates although the comparability of the findings across the two cohorts would suggest otherwise. The exclusion of children from NESB also arose due to differences in the constitution of the samples and further work to understand the risks of poor language outcomes for this group is recommended. The outcome measures in the two studies (the CELF-P2 and the PLS4) were different tests and by nature of their being used across different populations might be predicted to give different results. However, if the standardisation samples were well constructed this should not be problematic.

\section{Conclusions and future directions}

Early intervention for children at risk of later difficulties is considered a priority in most developed countries, but rarely are sufficient universal services in place to address concerns. Strategic-targeting has become the watchword for those responsible for providing such services. This opens up the 
Predicting school-entry language skills at 1 year

question of how best to identify the target group. Should one target the children with parents in the lowest socio-demographic quintile even though we know that not all of these children will need extra help and that many in other social groups who would not be picked up using this method will stand to benefit from additional support? Screening for early delays whether cognitive or linguistic, is appealing as a concept, but as our data show it is fraught with difficulties in terms of both the measures and the degree of variability in child development. This does not stop it being a focus for enquiry for those delivering services to those perceived to be the most in need in society in the early years. Our data suggest that very early identification using a 'risk model' drawing on robust predictors and tested in population samples, has the potential to act as a starting point for population monitoring. By contrast 'one-off' screens will never be sufficient and regular monitoring by child development services is likely to be the solution. Future research using population samples should evaluate the most cost-effective methods for targeting early preventative interventions, and the development of clinically applicable 'risk tools' and 'brief language interventions' should be explored.

\section{$\underline{\text { References }}$}

Australian Bureau of Statistics (2001). Socio-Economic Indexes for Areas. Canberra: Australian Bureau of Statistics.

Bishop, D. V. M. (2014). Ten questions about terminology for children with unexplained language problems. International Journal of Language and Communication Disorders, 49(4), 381-415.

Brigance, A. H., \& Frances, P. G. (2002). Brigance Infant and Toddler Screen. North Billerica, MA: Curriculum Associates.

Catts, H. W., Bridges, M. S., Little, T. D., \& Tomblin, J. B. (2008). Reading achievement growth in children with language impairments. Journal of Speech, Language, and Hearing Research, 51(6), 1569-1579.

Department for Education. (2010). Schools, pupils and their characteristics: January 2010 Local Authority Tables. from Department for Education, Gov.uk. Retrieved from 
Predicting school-entry language skills at 1 year

https://www.gov.uk/government/publications/schools-pupils-and-their-characteristicsjanuary-2010

Fenson, L., Dale, P. S., Reznick, J. S., Thal, D. J., Bates, E., Hartung, J. P., et al. (1997). MacArthur Communicative Development Inventories: User's guide and technical manual San Diego, CA: Singular Publishing Group Inc.

Field, F. (2010). The Foundation Years: preventing poor children becoming poor adults. London: HM Government.

Hambidge, S. J., Phibbs, S. L., Chandramouli, V., Fairclough, D., \& Steiner, J. F. (2009). A stepped intervention increases well-child care and immunization rates in a disadvantaged population. Pediatrics, 124(2), 455-464.

Johnson, C. J., Beitchman, J. H., Young, A., Escobar, M., Atkinson, L., Wilson, B., et al. (1999). Fourteen-year follow-up of children with and without speech/language impairments: Speech/language stability and outcomes. Journal of Speech, Language and Hearing Research, 42(3), 744-760.

Kirkwood, B. J., \& Sterne, J. A. C. (2003). Essential medical statistics (2nd ed.). Oxford, UK: Blackwell Sciences.

Law, J., Reilly, S., \& Snow, P. C. (2013). Child speech, language and communication needs reexamined in a public health context: a new direction for the speech and language therapy profession. International Journal of Language and Communication Disorders, 48(5), 486-496.

Law, J., Rush, R., Anandan, C., Cox, M., \& Wood, R. (2012). Predicting language change between 3 and 5 Years and its implications for early identification. Pediatrics, 130(1), 132-137.

Law, J., Rush, R., Schoon, I., \& Parsons, S. (2009). Modeling developmental language difficulties from school entry into adulthood: Literacy, mental health, and employment outcomes. Journal of Speech Language and Hearing Research, 52(6), 1401-1416.

Lee, J. (2011). Size matters: Early vocabulary as a predictor of language and literacy competence. Applied Psycholinguistics, 32(1), 69-92. 
Predicting school-entry language skills at 1 year

Lowell, D. I., Carter, A. S., Godoy, I., Paulicin, B., \& Briggs-Gowan, M. J. (2011). A randomized controlled trial of Child FIRST: A comprehensive home-based intervention translating research into early childhood practice. Child Development, 82(1), 193-208.

Marmot, M., Atkinson, A., Bell, J., Black, C., Broadfoot, P., Cumberlege, J., et al. (2010). Strategic review of health inequalities in England post - 2010: Fair society healthy lives: the Marmot review. London, UK: UCL.

McKean, C., Mensah, F. K., Eadie, P., Bavin, E. L., Bretherton, L., Cini, E., et al. (2015). Levers for language growth: Characteristics and predictors of language trajectories between 4 and 7 years. PLOS one, 10(8). 10.1371/journal.pone.0134251.

National Research Council and Institute of Medicine. (2000). From Neurons to Neighborhoods: The Science of Early Childhood Development. (9780309069885). Washington, D. C.: The National Academies Press. Retrieved from http://www.nap.edu/openbook.php?record id=9824.

Nelson, H. D., Nygren, P., Walker, M., \& Panoscha, R. (2006). Screening for speech and language delay: Systematic evidence review for the US Preventive Services Task Force. Pediatrics, 117(2), e298-e319.

Office for National Statistics. (2011). Census: Aggregate data (England and Wales). from UK Data Service Census Support, Office for National Statistics. Retrieved from $\underline{\text { http://infuse.mimas.ac.uk }}$

Prior, M. R., Sanson, A. V., \& Oberklaid, F. (1989). The Australian temperament project. In G. A. Kohnstamm, J. E. Bates, \& M. K. Rothbart (Eds.), Temperament in childhood (pp. 537-554). Oxford, UK: John WIley \& Sons.

Reilly, S., McKean, C., Morgan, A., \& Wake, M. (2015). Identifying and managing common childhood language and speech impairments. British Medical Journal (Clinical research ed.), 350, h2318. 
Predicting school-entry language skills at 1 year

Reilly, S., Tomblin, B., Law, J., McKean, C., Mensah, F., Morgan, A., .. Wake, M. (2014). SLI: a convenient label for whom? International Journal of Language \& Communication Disorders, 49(4), 416-451.

Reilly, S., Wake, M., Ukoumunne, O. C., Bavin, E., Prior, M., Cini, E., ... Bretherton, L. (2010). Predicting language outcomes at 4 years of age: Findings from the Early Language in Victoria Study. Pediatrics, 126(6), e1530-e1537.

Roberts, M. Y., \& Kaiser, A. P. (2011). The effectiveness of parent-implemented language interventions: A meta-analysis. American Journal of Speech-Language Pathology, 20(3), 180199.

Robinson, B. F., \& Mervis, C. B. (1999). Comparing productive vocabulary measures from the CDI and a systematic diary study. Journal of Child Language, 26, 177-185.

Roulstone, S., Law, J., Rush, R., Clegg, J., \& Peters, T. (2011). Investigating the role of language in children's early educational outcomes: An analysis of data from the Avon Longitudinal Study of Parents and Children (ALSPAC). Nottingham, UK: Department of Education.

Shonkoff, J. P. (2011). Protecting brains, not simply stimulating minds. Science, 333, 982-983.

Siu, A. L. (2015). Screening for speech and language delay in children 5 years old and younger: US preventive services task force recommendation statement. Pediatrics, 136(2), e474-e481.

Smith, L. (1998). Predicting communicative competence at 2 and 3 years from pragmatic skills at 10 months. International Journal of Language \& Communication Disorders, 33, 127-148.

Snowling, M. J., Duff, F. J., Nash, H. M., \& Hulme, C. (2015). Language profiles and literacy outcomes of children with resolving, emerging, or persisting language impairments. [Epub]. Journal of Child Psychology and Psychiatry.

StataCorp. (2013). Stata Statistical Software: Release 13. College Station, TX: StataCorp LP.

Tomasello, M. (2008). Origins of human communications. London, UK: MIT Press. 
Predicting school-entry language skills at 1 year

Wallace, I. F., Berkman, N. D., Watson, L. R., Coyne-Beasley, T., Wood, C. T., Cullen, K., \& Lohr, K. N. (2015). Screening for speech and language delay in children 5 years old and younger: A systematic review. Pediatrics, 136(2), e448-e462

Wetherby, A., \& Prizant, B. (2002). Communication and Symbolic Behaviour Scales. Baltimore, MD: Paul H Brookes.

Wiig, E. H., Secord, W. A., \& Semel, E. (2006). Clinical Evaluation of Language Fundamentals Preschool: Australian Standardised Edition (2ed.). Sydney, Australia: Harcourt Assessment. World Health Organisation (2010). Brief intervention: the ASSIST-linked brief intervention for hazardous and harmful substance use: Manual for use in primary care. Geneva, Switzerland: World Health Organisation.

Zambrana, I. M., Pons, F., Eadie, P., \& Ystrom, E. (2013). Trajectories of language delay from age 3 to 5: persistence, recovery and late onset. International Journal of Language and Communication Disorders.

Zimmerman, I. L., Steiner, V. G., \& Pond, R. E. (2002). The Preschool Language Scales - Fourth Edition (PLS4). London, UK: The Psychological Corporation. 


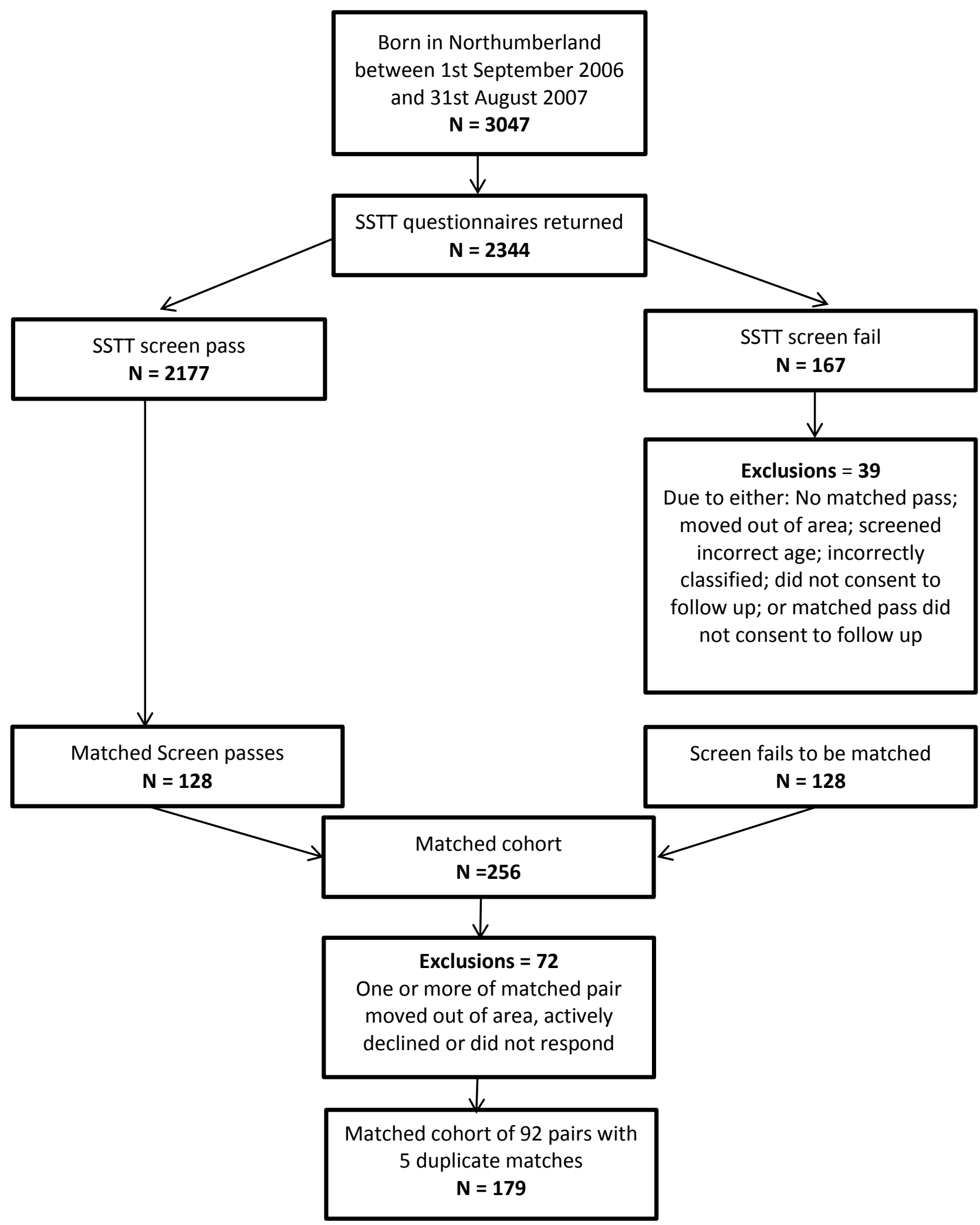

Figure 1. Flow diagram for Phase 1: Matched cohort methodology 
Predicting school-entry language skills at 1 year

\begin{tabular}{|c|c|c|c|c|c|c|c|}
\hline \multirow[b]{2}{*}{ Domain and Test } & \multirow[b]{2}{*}{ Subscales } & \multicolumn{2}{|c|}{ SSTT Fail } & \multicolumn{2}{|c|}{ SSTT Pass } & \multirow[b]{2}{*}{$\begin{array}{c}\text { Mean } \\
\text { difference }\end{array}$} & \multirow[b]{2}{*}{$95 \% \mathrm{Cl}$} \\
\hline & & $n$ & $\begin{array}{l}\text { Mean } \\
\text { (SD) }\end{array}$ & $n$ & $\begin{array}{l}\text { Mean } \\
\text { (SD) }\end{array}$ & & \\
\hline \multirow{3}{*}{ Language (PLS) } & PLS A & 2 & $\begin{array}{l}90.52 \\
(17.39)\end{array}$ & 7 & $\begin{array}{l}100.31 \\
(14.54)\end{array}$ & $-9.75^{* * *}$ & -14.33 to -5.18 \\
\hline & PLS B & 9 & $\begin{array}{r}89.35 \\
(17.84)\end{array}$ & 8 & $\begin{array}{l}100.31 \\
(14.53)\end{array}$ & $-10.96 * * *$ & -15.78 to -6.15 \\
\hline & PLS Total & 9 & $\begin{array}{l}90.33 \\
(17.97)\end{array}$ & 8 & $\begin{array}{l}100.23 \\
(13.85)\end{array}$ & $-9.89 * * *$ & -14.64 to -5.14 \\
\hline
\end{tabular}

Key: ${ }^{*} \mathrm{p}<.05 ;{ }^{* *} \mathrm{p}<.01{ }^{* * *} \mathrm{p}<.001 ;$ NS non-significant; ${ }^{\text {a }}$ equal variances not assumed; PLS Preschool Language Scales (PLS) (Zimmerman et al. 2002);

Table 1. Group comparisons between the children who failed SSTT at 12 months and their matched controls in language outcome at 4 years 


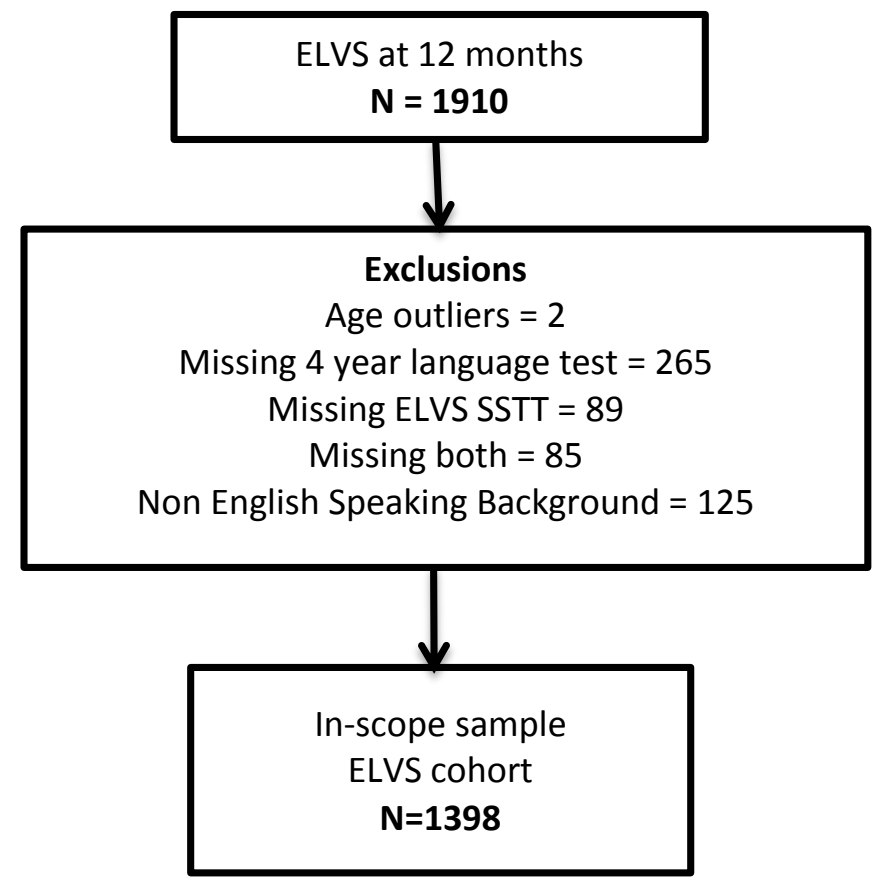

Figure 2. Flow diagram for generation of in-scope sample of the ELVS cohort 
Predicting school-entry language skills at 1 year 


\begin{tabular}{|c|c|c|c|c|c|c|c|c|c|c|c|}
\hline & & \multicolumn{10}{|c|}{ Low Language Status at 4 years $(N=1398)$} \\
\hline & & & \multicolumn{3}{|c|}{ Model 1} & \multicolumn{2}{|c|}{ Model 2} & \multirow[b]{2}{*}{ AUC } & \multicolumn{3}{|c|}{ Model 3} \\
\hline & & & OR $(95 \% \mathrm{Cl})$ & $p$ & AUC & OR $(95 \% \mathrm{Cl})$ & $p$ & & OR $(95 \% \mathrm{Cl})$ & $p$ & AUC \\
\hline Communicative & Showing* & (reference Not yet) & & & & & & & & & \\
\hline \multirow{4}{*}{ Behaviours } & Words/phrases understood* & $\begin{array}{r}\text { Often } \\
\text { (reference } 0-3 \text { ) }\end{array}$ & $.32(.19$ to .53$)$ & $<.001$ & & $.34(.20$ to .57$)$ & $<.001$ & & .37 (.22 to.65) & $<.001$ & \\
\hline & & $4-10$ & .65 (.48 to .88$)$ & .005 & & $.60(.44$ to .83$)$ & .002 & & .64 (.46 to .88$)$ & .005 & \\
\hline & Words used meaningfully* & $\begin{array}{r}11 \text { and over } \\
\text { (reference 0-10) }\end{array}$ & $.57(.33$ to .97$)$ & .040 & & .51 (.29 to .89$)$ & .019 & & $.53(.30$ to .94$)$ & .028 & \\
\hline & & $>11$ & .25 (.06 to .1 .1$)$ & .061 & .63 & .24 (.06 to 1.04$)$ & .057 & & $.25(.06$ to 1.12$)$ & .070 & \\
\hline \multirow[t]{5}{*}{$\begin{array}{l}\text { Family } \\
\text { Characteristics }\end{array}$} & Family History* & & & & & $\begin{array}{c}1.65(1.20 \text { to } \\
2.25)\end{array}$ & .002 & & $\begin{array}{c}1.66(1.21 \text { to } \\
2.28)\end{array}$ & .002 & \\
\hline & Maternal Education & (reference $\leq$ Year 12) & & & & & & & & & \\
\hline & SEIFA quintile & $\begin{array}{l}\text { Degree or postgraduate } \\
\text { (reference } 1,2,3 \text { ) }\end{array}$ & & & & $.47(.33$ to .66$)$ & $<.001$ & & .48 (.34 to .68$)$ & $<.001$ & \\
\hline & & 4 & & & & $.42(.29$ to .62$)$ & $<.001$ & & .41 (.28 to .60$)$ & $<.001$ & \\
\hline & & & & & & & & .71 & & & \\
\hline \multirow[t]{3}{*}{$\begin{array}{l}\text { Parental } \\
\text { Behaviours }\end{array}$} & Talk about toy & $\begin{array}{r}\text { (reference not very } \\
\text { often) }\end{array}$ & & & & & & & & & \\
\hline & & Sometimes & & & & & & & .37 (.21 to .64$)$ & $<.001$ & \\
\hline & & Often & & & & & & & .30 (.17 to .53$)$ & $<.001$ & \\
\hline
\end{tabular}

*Questions included in ELVS-SSTT Tool Note: Showing = "Child extends arm to show you something s/he is holding" Words/phrases understood = "How many different words or phrases does your child understand without gestures, for example if you say "where's daddy", "give me the ball" or "come here" without showing or pointing your child will respond appropriately. Words used meaningfully = "How many different words does your child use meaningfully" Talk about a toy = "When my child looks at/touches a toy I talk about it".

Table 2 Final Multiple Logistic Regression Models resulting from hierarchical analysis: relationship between Communicative Behaviours, Family characteristics and Parental behaviours with Language status at 4 years. 


\section{Appendix: SSTT and ELVS-SSTT Questions}

\begin{tabular}{|c|c|c|c|c|}
\hline & SSTT Questions & Response & ELVS-SSTT conceptually matched questions & Response \\
\hline 1 & $\begin{array}{l}\text { When s/he wants you to pay attention to something, does s/he hold out } \\
\text { something for you to look at? }\end{array}$ & \multirow{10}{*}{$\begin{array}{l}\text { O You have } \\
\text { not seen } \\
\text { your child } \\
\text { do this yet. } \\
1 \mathrm{He} / \text { she } \\
\text { has just } \\
\text { started to } \\
\text { do this in } \\
\text { the last few } \\
\text { days. } \\
2 \text { He/she } \\
\text { has been }\end{array}$} & Extends arm to show you something he/she is holding a & $\mathrm{NY} / \mathrm{ST} / \mathrm{OFT}$ \\
\hline 2 & $\begin{array}{l}\text { Does s/he use any words or sounds that you recognise for special people or } \\
\text { things? e.g. a sound to call your pet or a sound that means nana. }\end{array}$ & & How many different words does your child use meaningfully? ${ }^{b}$ & $\begin{array}{l}\text { None; } 1-3 ; \\
4-10 ; 11-30 ; \\
\text { over } 30\end{array}$ \\
\hline 3 & Does s/he ever look at you and reach for something s/he can't get? & & Does your child let you know that he/she needs help or wants an object out of reach? ${ }^{b}$ & NY/ST/OFT \\
\hline 4 & $\begin{array}{l}\text { Can s/he give you one object from a group of objects when you ask for it by } \\
\text { name? e.g. if your child had a book, ball, shoe and spoon could s/he give you } \\
\text { the ball when you asked for it. }\end{array}$ & & Checklist of Early Words Understood ${ }^{a}$ & $\begin{array}{l}\text { Score } 0 \text { or } \\
\geq 1\end{array}$ \\
\hline 5 & If you wave and say "bye bye" does s/he ever wave back. & & Waves bye-bye on his/her own when someone leaves ${ }^{a}$ & NY/ST/OFT \\
\hline 6 & $\begin{array}{l}\text { Does s/he show you s/he understands some of the things that you say? e.g. } \\
\text { 'Here comes nana' - and s/he looks to the door. Or 'time for a bath' - and s/he } \\
\text { moves to the bathroom }\end{array}$ & & $\begin{array}{l}\text { How many different words or phrases does your child understand without gestures. For } \\
\text { example if you say "where's your tummy", "where's daddy", "give me ball", or "come here" } \\
\text { without showing or pointing, your child will respond appropriately b }\end{array}$ & $\begin{array}{l}\text { None; } 1-3 ; \\
4-10 ; 11-30 \\
\text { over } 30\end{array}$ \\
\hline 7 & Does s/he ever copy words or sounds that you make e.g." hiya" or "boo" & & $\begin{array}{l}\text { Some children like to "parrot" or imitate things that they've just heard (including new } \\
\text { words that they are just learning, and / or parts of sentences, for example, repeating "work } \\
\text { now" after mother says "Mummy's going to work now.") How often does your child imitate } \\
\text { words? a }\end{array}$ & $\begin{array}{l}\text { Never ST } \\
\text { OFT }\end{array}$ \\
\hline 8 & $\begin{array}{l}\text { Does s/he show you s/he understands what some objects \& toys are used for? } \\
\text { e.g. touch a brush to his/her hair? Or a shoe to his/her foot? Or push a toy car } \\
\text { along? }\end{array}$ & & Checklist of Actions with Objects a & $\begin{array}{l}\text { Score } 0 \text { or } \\
\geq 1\end{array}$ \\
\hline 9 & $\begin{array}{l}\text { When you want to get him/her to pay attention to something, does s/he look } \\
\text { where you are looking and where you are pointing? }\end{array}$ & & When you look at and point to a toy across the room, does your child look at it? ${ }^{b}$ & NY/ST/OFT \\
\hline 10 & $\begin{array}{l}\text { At meal times, does s/he ever share food with you by holding it to your } \\
\text { mouth? }\end{array}$ & & Reaches out and gives you a toy or some object that he/she is holding ${ }^{a}$ & NY/ST/OFT \\
\hline 11 & Has anybody in the immediate family received Speech and Language Therapy? & 0 Yes 1 No & $\begin{array}{c}\text { Has child's mother, father or any of the child's siblings } \\
-\quad \text { been late to talk } \\
-\quad \text { had ongoing problems with speech/language during childhood } \\
-\quad \text { had problems with stuttering } \\
-\quad \text { had problems learning to read }{ }^{c}\end{array}$ & Yes/No* \\
\hline 12 & $\begin{array}{l}\text { Are there any concerns about your child's hearing? (Mark yes if you are } \\
\text { concerned, if they have had a number of ear infections or failed their most } \\
\text { recent hearing test) }\end{array}$ & & Have you been concerned that your child might have a hearing loss? $c, d$ & Yes/No** \\
\hline
\end{tabular}

Key: NY/ST/OFT = Not Yet/Sometimes/Often; a MCDI - McArthur-Bates Communicative Development Inventories; b CSBS Communication and Symbolic Behaviour Scales; c ELVS research questionnaires at 8 months; d ELVS research questionnaires at 12 months; *Yes if any marked Yes/No if all marked No; **Yes - if marked Yes at either 8 or 12 months/No - if marked No at both 8 and 12 months 